\title{
Characterization and Pathogenicity of Botryosphaeriaceae Species Isolated from Almond Trees on the Island of Mallorca (Spain)
}

Diego Olmo, Laboratori de Sanitat Vegetal, Serveis de Millora Agrària, Conselleria d'Agricultura, Medi Ambient i Territori, Govern Balear, C/d'Eusebi Estada 145, 07008 Palma de Mallorca, Spain; Josep Armengol and Maela León, Instituto Agroforestal Mediterráneo, Universidad Politécnica de Valencia, Camino de Vera s/n, 46022 Valencia, Spain; and David Gramaje, Instituto de Ciencias de la Vid y del Vino (ICVV), Consejo Superior de Investigaciones Científicas, Universidad de la Rioja, Gobierno de La Rioja, Ctra. LO-20 Salida 13, Finca La Grajera, 26071 Logroño, Spain

\begin{abstract}
Olmo, D., Armengol, J., León, M., and Gramaje, D. 2016. Characterization and pathogenicity of Botryosphaeriaceae species isolated from almond trees on the island of Mallorca (Spain). Plant Dis. 100:2483-2491.

In this study, 31 almond orchards with trees showing severe decline symptoms were surveyed from 2009 to 2014 on the island of Mallorca (Spain). In all, 45 Botryosphaeriaceae isolates were collected and characterized based on phenotypical features and comparisons of DNA sequence data of the nuclear ribosomal DNA-internal transcribed spacer region and elongation factor $1-\alpha$ gene. Five species were identified as Diplodia olivarum, D. seriata, Neofusicoccum luteum, $N$. mediterraneum,

and $N$. parvum. Pathogenicity tests were performed on four cultivars ('Pons', 'Vivot', 'Jordi', and 'Ferragnes') under field conditions for two consecutive years (2013 to 2014), and confirmed that all five species cause canker and dieback of almond, with Neofusicoccum spp. more virulent than Diplodia spp. in both years. Jordi was less sensitive to fungal infection in 2013. First reports from almond in Spain include N. mediterraneum and N. luteum.
\end{abstract}

Almond seed is among the richest sources of health-benefiting nutrients essential for optimum health, particularly minerals, proteins, vitamins, and monounsaturated fatty acids. The worldwide production and consumption of almond has been increasing rapidly in recent years. For example, almond recently overtook peanut as the most eaten seed in the United States, and Americans now consume more than 10 times as many almond nuts as they did in 1965 . The meteoric rise of the tree-nut is driven, in part, by the nut's myriad health benefits (Nishi et al. 2014).

Spain is the third largest almond producer after California and Australia (FAOSTAT 2013). The Spanish almond industry presently occupies 127,556 ha (INE 2014) and yielded 2.9 million tons in 2013 (FAOSTAT 2013), representing $5.11 \%$ of the world production (FAOSTAT 2013). In Spain, the Balearic Islands (western Mediterranean Sea) is considered an important region for almond production, with 24,443 ha of this crop cultivated in 2014 (INE 2014).

Members of the family Botryosphaeriaceae have a worldwide distribution and cause cankers, dieback, leaf spots, fruit rot, and eventual death on many economically important woody perennial crops (Brown and Britton 1986; Pusey et al. 1995). In Spain, species of Botryosphaeriaceae have been reported causing diseases on many fruit and nut trees, such as almond (Prunus dulcis; Gramaje et al. 2012), avocado (Persea americana; Zea-Bonilla et al. 2007), grapevine (Vitis vinifera; Armengol et al. 2001), olive (Olea europaea; Moral et al. 2008, 2010), pistachio (Pistacia vera; Armengol et al. 2008), plum (Prunus domestica; Roca et al. 2013), and southern highbush blueberry (Vaccinium spp.; Castillo et al. 2013). The disease symptoms caused by the species of Botryosphaeriaceae on fruit and nut trees in Spain include death of twigs and branches, cankers, stem dieback, and fruit rot (Armengol et al. 2001, 2008; Castillo et al. 2013; Gramaje et al. 2012; Moral et al. 2008, 2010; Roca et al. 2013; Zea-Bonilla et al. 2007).

During the last 6 years, many almond trees with symptoms of decay have been observed in several orchards on the island of Mallorca

Corresponding author: D. Gramaje; E-mail: david.gramaje@icvv.es

Accepted for publication 3 August 2016.

http://dx.doi.org/10.1094/PDIS-05-16-0676-RE

(C) 2016 The American Phytopathological Society
(Balearic Islands). Diseased plants were characterized by dead branches; leaf chlorosis, in which leaves suddenly wilted and died; as well as bud and shoot dieback. Dissected wood showed black spots or circular discoloration of the xylem vessels, and wedgeshaped necroses. Preliminary research about fungal trunk pathogen detection resulted in the identification of five species of Botryosphaeriaceae; namely, Botryosphaeria dothidea, Diplodia olivarum, D. seriata, Neofusicoccum australe, and N. parvum (Gramaje et al. 2012). All these species were isolated from diseased almond stems, branches, or twigs.

These previous results suggested that members of the family Botryosphaeriaceae could constitute a threat to the almond industry on Mallorca where, currently, only Armillaria root rot (Armillaria mellea), brown rot and blossom blight (Monilinia spp.), and Phomopsis branch dieback (Phomopsis amygdali) are considered diseases of economic importance. Thus, the objectives of this study were to (i) conduct extensive surveys in almond orchards and identify the species of Botryosphaeriaceae associated with wood decay of almond trees based on phenotypical and molecular methods, and (ii) determine the pathogenicity of various isolates and compare the tolerance of several almond cultivars to these fungi.

\section{Materials and Methods}

Field survey and fungal isolation. Isolates used in this study were collected from almond trees ('Bord d'en Bessó', Cristomorto', 'Ferragnes', 'Ferranduel', 'Garrigues', 'Glorieta', 'Guara', 'Guarín', 'Jordi', 'Masbovera', 'Menor', 'Negre', 'Pons', 'Poteta', 'Ribes', 'Totsolet', 'Verdereta', 'Vinagrillos', and 'Vivot') showing dieback symptoms in different locations of the Es Raiguer, Llevant, Mitjorn, and Pla regions on the island of Mallorca (Balearic Islands, western Mediterranean Sea) from 2009 to 2014 (Table 1). In total, 31 field sites were selected across an area of approximately $2,600 \mathrm{~km}^{2}$. Approximately 10 to 15 pieces of trunks and branches with canker symptoms were collected from four to five randomly selected trees in each of the field sites.

Sections of discolored wood $(10 \mathrm{~cm}$ long) were cut from diseased branches and shoots of almond trees, washed under running tap water, surface sterilized in $1.5 \%$ sodium hypochlorite for $1 \mathrm{~min}$, rinsed twice with sterile distilled water, and plated on malt extract agar (Difco Laboratories) supplemented with streptomycin sulfate (MEAS) at $0.5 \mathrm{~g} /$ liter (Sigma-Aldrich Laboratories). Isolation plates were incubated at 25 to $26^{\circ} \mathrm{C}$ in darkness for 14 to 21 days, and all colonies were 
subcultured to potato dextrose agar (PDA; Biokar-Diagnostics Laboratories). All isolates were hyphal tipped in order to obtain pure cultures and stored in $15 \%$ glycerol solution at $-80^{\circ} \mathrm{C}$ in 1.5 -ml cryovials.

Morphological identification and characterization. Isolates were identified based on colony morphology (isolates with fastgrowing mycelium, fluffy, white to gray-green) and conidial characteristics (i, thin-walled, narrow, and Fusicoccum-like conidia or ii, thick-walled, wider, and Diplodia-like conidia), as described by Phillips et al. (2013). For sporulation, cultures were grown on $2 \%$ water agar (WA; Biokar-Diagnostics Laboratories) bearing sterilized pine needles and incubated at $25^{\circ} \mathrm{C}$ under near-UV light with a 12 -h photoperiod (Slippers et al. 2004). Isolates were examined weekly for formation of pycnidia and conidia. Conidia oozing from the ostioles were mounted in $100 \%$ lactic acid. The length and width of 50 conidia for each isolate were measured at $\times 1,000$ magnification with a compound Nikon Eclipse Ni-e microscope. Minimum, maximum, mean, and standard deviation were calculated from measurements.
Conidial shape and color and the presence of septa were also recorded. Three isolates of each Botryosphaeriaceae sp. were randomly selected for conidial measurements and temperature-growth assay. Three petri dishes per isolate were used and all experiments were performed twice. Colony morphological characteristics were observed and colony colors were determined with the color chart of Rayner (1970).

Effect of temperature on mycelial growth. Mycelial plugs ( $5 \mathrm{~mm}$ in diameter) obtained from 15 actively growing isolates (Table 1) were transferred to the center of PDA petri dishes and incubated in darkness from 5 to $35^{\circ} \mathrm{C}$ at $5^{\circ} \mathrm{C}$ intervals. Colony diameter was measured daily during 4 days. Six replicate plates per isolate were used and the experiment was conducted twice. Student's $t$ test least significant difference (LSD) was calculated at the 5\% significance level to compare treatment means between experiments. Regression curves were fitted to the values of radial growth (millimeters per day) versus temperature for each isolate. Two parameters were calculated in the fitted equation for each isolate: optimum temperature $\left({ }^{\circ} \mathrm{C}\right)$ for radial

Table 1. Isolates of Botryosphaeriaceae spp. recovered from almond samples on Mallorca Island used in this study

\begin{tabular}{|c|c|c|c|c|}
\hline \multirow[b]{2}{*}{ Species } & \multirow[b]{2}{*}{ Isolate } & \multirow[b]{2}{*}{ Location } & \multicolumn{2}{|c|}{ GenBank accession number ${ }^{x}$} \\
\hline & & & ITS & EF \\
\hline Diplodia olivarum & BAL-1 ${ }^{\mathrm{y}}$ & Sant Llorenç des Cardassar & KX029136 & KX029182 \\
\hline D. olivarum & BAL-2 & Llucmajor & KX029137 & KX029183 \\
\hline D. olivarum & BAL-27 & Llucmajor & KX029162 & KX029207 \\
\hline D. olivarum & BAL-28 & Llucmajor & KX029163 & KX029208 \\
\hline D. olivarum & BAL-29 & Llucmajor & KX029164 & KX029209 \\
\hline D. olivarum & BAL- $-35^{z}$ & Binissalem & KX029170 & KX029215 \\
\hline D. olivarum & BAL-39z & Sant Llorenç des Cardassar & KX029174 & KX029219 \\
\hline D. olivarum & BAL-40 & Sant Llorenç des Cardassar & KX029175 & KX029220 \\
\hline D. olivarum & BAL- $43^{z}$ & Sant Llorenç des Cardassar & KX029178 & KX029223 \\
\hline D. olivarum & BAL-44 & Sant Llorenç des Cardassar & KX029179 & KX029224 \\
\hline D. seriata & BAL-4y & Santa María & KX029139 & KX029185 \\
\hline D. seriata & BAL-10 $10^{z}$ & Sant Llorenç des Cardassar & KX029145 & KX029191 \\
\hline D. seriata & BAL-12 & Santa María & KX029147 & KX029193 \\
\hline D. seriata & BAL-16 & Santa María & KX029151 & KX029197 \\
\hline D. seriata & BAL-19 & Llucmajor & KX029154 & KX029200 \\
\hline D. seriata & BAL-20 & Llucmajor & KX029155 & KX029201 \\
\hline D. seriata & BAL-22 & Llucmajor & KX029157 & KX029203 \\
\hline D. seriata & BAL-24 & Llucmajor & KX029159 & KX029205 \\
\hline D. seriata & BAL-25 & Llucmajor & KX029160 & KX029206 \\
\hline D. seriata & BAL-36 & Binissalem & KX029171 & KX029216 \\
\hline D. seriata & BAL- $45^{\mathrm{z}}$ & Binissalem & KX029180 & KX029225 \\
\hline Neofusicoccum luteum & BAL-6y & Sant Llorenç des Cardassar & KX029141 & KX029187 \\
\hline N. luteum & BAL-18 & Llucmajor & KX029153 & KX029199 \\
\hline N. luteum & BAL-21 & Llucmajor & KX029156 & KX029202 \\
\hline N. luteum & BAL-23 & Llucmajor & KX029158 & KX029204 \\
\hline N. luteum & BAL-26 & Llucmajor & KX029161 & KX029181 \\
\hline N. luteum & $\mathrm{BAL}-30^{\mathrm{z}}$ & Llucmajor & KX029165 & KX029210 \\
\hline N. luteum & BAL-31 & Llucmajor & KX029166 & KX029211 \\
\hline N. luteum & BAL-32 & Llucmajor & KX029167 & KX029212 \\
\hline N. luteum & BAL- $33^{z}$ & Llucmajor & KX029168 & KX029213 \\
\hline N. luteum & BAL-34z & Llucmajor & KX029169 & KX029214 \\
\hline N. mediterraneum & BAL-3y,z & Sant Llorenç des Cardassar & KX029138 & KX029184 \\
\hline N. mediterraneum & BAL-5 & Sant Llorenç des Cardassar & KX029140 & KX029186 \\
\hline N. mediterraneum & BAL-11 & Sant Llorenç des Cardassar & KX029146 & KX029192 \\
\hline N. mediterraneum & BAL-13 & Sant Llorenç des Cardassar & KX029148 & KX029194 \\
\hline N. mediterraneum & BAL-14 & Sant Llorenç des Cardassar & KX029149 & KX029195 \\
\hline N. mediterraneum & BAL-15z & Sant Llorenç des Cardassar & KX029150 & KX029196 \\
\hline N. mediterraneum & BAL-17 & Sant Llorenç des Cardassar & KX029152 & KX029198 \\
\hline N. mediterraneum & BAL-37z & Santa María & KX029172 & KX029217 \\
\hline N. mediterraneum & BAL-38 & Sant Llorenç des Cardassar & KX029173 & KX029218 \\
\hline N. parvum & BAL-7y,z & Sant Llorenç des Cardassar & KX029142 & KX029188 \\
\hline N. parvum & BAL-8 & Sant Llorenç des Cardassar & KX029143 & KX029189 \\
\hline N. parvum & BAL-9 & Sant Llorenç des Cardassar & KX029144 & KX029190 \\
\hline N. parvum & BAL- $41^{z}$ & Sant Llorenç des Cardassar & KX029176 & KX029221 \\
\hline N. parvum & BAL- $42^{z}$ & Sant Llorenç des Cardassar & KX029177 & KX029222 \\
\hline
\end{tabular}

${ }^{\mathrm{x}}$ ITS $=$ internal transcribed spacer and $\mathrm{EF}=$ elongation factor $1-\alpha$.

${ }^{\mathrm{y}}$ Isolates used for pathogenicity tests.

${ }^{\mathrm{z}}$ Isolates used for colony and conidial morphology, and in the temperature growth assay. 
growth and maximum daily radial growth (millimeters per day). Data were analyzed using the Kruskal-Wallis test and mean ranks of isolates were compared at $P=0.05$ using Dunn's test.

Molecular characterization and phylogenetic analyses. Total genomic DNA was extracted from fresh mycelium after 2 weeks of incubation in PDA using the E.Z.N.A. Plant Miniprep Kit (Omega Bio-tek) following the manufacturer's instructions. The internal transcribed spacer (ITS) region and part of the translation elongation factor $1-\alpha(E F 1-\alpha)$ were amplified and sequenced using the primer pairs ITS1F (Gardes and Bruns 1993)/ITS4 (White et al. 1990) and EF1F/ EF2R (Jacobs et al. 2004), respectively. Polymerase chain reactions (PCR) were performed using the HotBegan Taq DNA Polymerase (Canvax Biotech, S.L.) following the manufacturer's recommendations in a Peltier Thermal Cycler-200 (MJ Research). Amplification conditions included an initial denaturation step of $5 \mathrm{~min}$ at $94^{\circ} \mathrm{C}$, followed by 35 cycles of denaturation at $94^{\circ} \mathrm{C}$ for $30 \mathrm{~s}$, annealing at $55^{\circ} \mathrm{C}$ for $30 \mathrm{~s}$, and elongation at $72^{\circ} \mathrm{C}$ for $45 \mathrm{~s}$. A final extension was performed at $72^{\circ} \mathrm{C}$ for $10 \mathrm{~min}$. PCR products were visualized in $1.2 \%$ agarose gels (agarose D-1 Low EEO; Conda). PCR products were sequenced by Macrogen Inc. (Macrogen Europe). Sequences were assembled and edited using program Sequencher 5.0 (Gene Codes).

The ITS and EF1- $\alpha$ sequences of Botryosphaeriaceae isolates from almond cankers in the present study (Table 1) were compared with GenBank sequences of closely related species selected based on their high similarity to our sequences using BLAST (Table 2) and the outgroup Melanops tulasnei (CBS116805 and CBS116806; GenBank Accession numbers ITS: FJ824770 and FJ824769; and EF1- $\alpha$ : KF766423 and FJ824775). Clustal W sequence alignment and phylogenetic analysis (neighbor joining $[\mathrm{NJ}]$ and maximum likelihood [ML]) were performed using MEGA, version 7 (Kumar et al. 2016). Each sequence dataset (ITS and EF1- $\alpha$ ) was aligned with Clustal W using default settings. Alignments were checked, manual adjustments were made where necessary, and incomplete portions at either end were excluded. These alignments were concatenated to perform combined phylogenetic analysis.

ML analyses were performed on an NJ starting tree generated automatically by the software. The general time-reversible model of evolution, including estimation of invariable sites and assuming a discrete $\gamma$ distribution with six rate categories $(G T R+G+I)$, was used. Nearest-neighbor-interchange was used as the heuristic method for tree inference and 1,000 bootstrap replicates were performed. Gaps were treated as a phylogenetically relevant characteristics. New sequences were deposited in GenBank (Table 1) and the alignments and tree in TreeBase (https://treebase.org).

Pathogenicity tests. Two experiments were conducted from April 2013 to December 2013 (experiment 1) and from April 2014 to December 2014 (experiment 2) in a field site located in Palma de

Table 2. Botryosphaeriaceae isolates from GenBank included in the phylogenetic analyses

\begin{tabular}{|c|c|c|c|c|c|}
\hline \multirow[b]{2}{*}{ Species $^{\mathrm{z}}$} & \multirow[b]{2}{*}{ Isolate } & \multirow[b]{2}{*}{ Host } & \multirow[b]{2}{*}{ Origin } & \multicolumn{2}{|c|}{ GenBank accession number ${ }^{y}$} \\
\hline & & & & ITS & EF \\
\hline Diplodia africana* & CBS120835 & Prunus persica & South Africa & EF445343 & EF445382 \\
\hline D. africana & CBS121104 & P. persica & South Africa & EF445344 & EF445383 \\
\hline D. malorum & CAP267 & Malus sylvestris & Portugal & GQ923861 & GQ923829 \\
\hline D. malorum* & CBS124130 & M. sylvestris & Portugal & GQ923865 & GQ923833 \\
\hline D. mutila & CBS112553 & Vitis vinifera & Portugal & AY259093 & AY573219 \\
\hline D. mutila & CBS230.30 & Phoenix dactylifera & United States & DQ458886 & DQ458869 \\
\hline D. olivarum & CBS121886 & Olea europaea & Italy & EU392301 & EU392278 \\
\hline D. olivarum* ${ }^{*}$ & CBS121887 & O. europaea & Italy & EU392302 & EU392279 \\
\hline D. pseudoseriata & CMW38137 & Acacia karroo & South Africa & КC769954 & KC769863 \\
\hline D. pseudoseriata & UY107 & A. karroo & South Africa & EU080914 & EU863178 \\
\hline D. rosulata* & CBS116470 & Prunus africana & Ethiopia & EU430265 & EU430267 \\
\hline D. rosulata & CBS116472 & P. africana & Ethiopia & EU430266 & EU430268 \\
\hline D. sapinea & CBS109727 & Pinus radiata & South Africa & DQ458897 & DQ458882 \\
\hline D. sapinea & CBS109943 & P. patula & Indonesia & DQ458898 & DQ458883 \\
\hline D. scrobiculata & CBS109944 & P. greggii & Mexico & DQ458899 & DQ458884 \\
\hline D. scrobiculata & CBS113423 & P. greggii & Mexico & DQ458900 & DQ458885 \\
\hline D. seriata* & CBS112555 & V. vinifera & Portugal & AY259094 & AY573220 \\
\hline D. seriata & CBS119049 & V. vinifera & Italy & DQ458889 & DQ458874 \\
\hline Neofusicoccum arbuti & CBS117090 & Arbutus menziesii & United States & AY819724 & KF531791 \\
\hline N. arbuti & PD282 & A. menziesii & United States & GU251152 & GU251284 \\
\hline N. australe* & CMW6837 & Acacia sp. & Australia & KF766200 & AY339270 \\
\hline N. australe & CMW6853 & Sequiadendron giganteum & Australia & AY339263 & AY339271 \\
\hline N. brasiliense & CMM1269 & Mangifera indica & Brazil & JX513629 & JX513609 \\
\hline N. brasiliense & CMM1338 & M. indica & Brazil & JX513630 & JX513610 \\
\hline N. cryptoaustrale & CMW20738 & Eucalyptus citriodora & South Africa & FJ752740 & FJ752710 \\
\hline N. cryptoaustrale & CMW23785 & Eucalyptus sp. & South Africa & FJ752742 & FJ752713 \\
\hline N. luteum* & CBS110299 & $V$. vinifera & Portugal & AY259091 & AY573217 \\
\hline N. luteum & CBS110497 & V. vinifera & Portugal & EU673311 & EU673277 \\
\hline N. mediterraneum* & CBS121718 & Eucalyptus sp. & Greece & GU251176 & GU251308 \\
\hline N. mediterraneum & UCD720SJ & $V$. vinifera & United States & GU799452 & GU799483 \\
\hline N. parvum* & CMW9081 & Populus nigra & New Zealand & AY236943 & AY236888 \\
\hline N. parvum & CBS110301 & V. vinifera & Portugal & AY259098 & AY573221 \\
\hline N. ribis* & CBS115475 & Ribes sp. & United States & AY236935 & AY236877 \\
\hline N. ribis & CMW7773 & Ribes sp. & United States & AY236936 & DQ235142 \\
\hline N. ursorum & CMW23790 & Eucalyptus arboretum & South Africa & FJ752745 & FJ752708 \\
\hline N. ursorum* & CBS122811 & E. arboretum & South Africa & FJ752746 & FJ752709 \\
\hline N. vitifusiforme & CBS110880 & $V$. vinifera & South Africa & AY343382 & AY343344 \\
\hline N. vitifusiforme* & CBS110887 & V. vinifera & South Africa & AY343383 & AY343343 \\
\hline
\end{tabular}

${ }^{\mathrm{y}}$ ITS $=$ internal transcribed spacer and $\mathrm{EF}=$ elongation factor $1-\alpha$.

${ }^{\mathrm{z}}$ Asterisks $(*)$ indicate ex-type specimens. 
Mallorca, in which almond had never been grown. In December 2012, healthy 2-year-old dormant almond trees of four cultivars (Pons, Vivot, Jordi, and Ferragnes), grafted onto rootstock GF-677 (Prunus dulcis $\times P$. persica), were obtained from a commercial nursery and planted in rows spaced $1.2 \mathrm{~m}$ from tree to tree, with an in-row spacing of $4 \mathrm{~m}$, according to the experimental design described below.

One isolate each of five species in the Botryosphaeriaceae family which were recovered from almond cankers were used in the field pathogenicity tests (Table 1). Wounds were made on the woody stems of the trees with an 8-mm cork borer. Agar plugs (diameter $=8 \mathrm{~mm}$ ) were taken from 7-day-old culture grown on PDA and placed into the fresh wound. Three stems per isolate and cultivar were inoculated (one inoculated stem per tree). In addition, three stems of each of the four cultivars were wounded and inoculated with a sterile PDA plug and served as negative controls. In 2014, inoculated wood from the previous experiment (year 2013) was removed and only healthy wood was inoculated again as described above.

The experiment was set up in a split-plot design. Four whole replications were treated as a blocking factor, cultivar was treated as the whole-plot factor within each block (replication), and treatment was treated as the subplot factor randomly distributed within each cultivar, with three replications (trees) for each inoculation treatment, including uninoculated controls. Each block was $90 \mathrm{~m}$ long and included two rows, each with two cultivars and 18 almond trees per cultivar (72 trees per block, 288 trees). In 2014, the factor treatment was randomly distributed again within each cultivar.

Pathogenicity was evaluated at 9 months postinoculation, based on the length of wood lesions, which were revealed by cutting the stem longitudinally through the inoculation site. Extent of vascular discoloration was measured upward and downward from the inoculation point. Six small pieces of necrotic tissue were cut per lesion and placed on MEAS in an attempt to recover the inoculated fungi. Fungi were identified as described previously, fulfilling Koch's postulates.

Statistical analysis. Prior to analysis of variance (ANOVA), homogeneity of variance across treatments was evaluated using Levene's test (Box et al. 1978). To satisfy the assumption of homogeneity of variance, a square-root transformation to total lesion length was applied. Lesion length over 2 years was analyzed using ANOVA, with cultivar as the main plot, treatment as the subplot, and replicates as blocks. Data from all experiments were analyzed using the Statistix 10 software
(Analytical Software). Transformed data means were compared using Tukey's honestly significant difference test at $P=0.05$.

\section{Results}

Field survey. Botryosphaeriaceae spp. were the most common fungi isolated from almond trees with dieback symptoms, including dead shoots, cankers, and internal wood necrosis. Sampled trees ranged in age from approximately 10 to 80 years old. Based on colony morphology, phylogenetic analyses, and conidial characteristics (see below), 45 isolates belonging to the Botryosphaeriaceae family were identified. Neofusicoccum spp. accounted for $53.3 \%$ of all isolates, and the remaining isolates were identified as Diplodia spp. $D$. seriata and $N$. luteum were the most frequently recovered (each species in $29.03 \%$ of the field sites), followed by $N$. parvum $(25.8 \%$ of the field sites), D. olivarum (22.58\%), and N. mediterranum $(16.13 \%)$. Given the broad range of almond cultivars surveyed, we could not find any association among fungal species and almond cultivars.

The species Phaeoacremonium amygdalinum, P. iranianum, Collophora hispanica, Eutypa lata, E. leptoplaca, Fomitiporia mediterranea, Omphalotus olearius, Phellinus pomaceus, and Pleurostoma richardsiae were also sporadically isolated in almond branches, as well as various saprophytic contaminants (Alternaria, Aspergillus, and Penicillium spp.). However, only the Botryosphaeriaceae fungi were considered for this study.

Morphological characterization. All isolates produced pycnidia on WA supplemented with pine needles within 30 days. No ascomata were seen in culture. Based on the Botryosphaeriaceae family description, it was possible to separate two different groups among Neofusicoccum spp. isolates. The first consisted of isolates showing hyaline, aseptate, and broadly ellipsoid conidia. This matched descriptions for $N$. mediterraneum and $N$. parvum (Table 3 ), although $N$. parvum occasionally showed one and two-septate conidia. Measurements showed that conidia of $N$. mediterraneum were larger than those of $N$. parvum (Table 3 ). The second group of isolates had hyaline, aseptate, and fusiform conidia. Colonies of this group were characterized by pale-yellow to bright-yellow pigment in the center of the plate. These characteristics (Table 3) matched those described earlier for N. australe or N. luteum (Phillips et al. 2013). The identity of $N$. luteum was further confirmed by molecular methods.

Two species of Diplodia were morphologically distinguished: D. olivarum, which showed conidia that were hyaline, thick-walled,

Table 3. Conidial measurements of Botryosphaeriaceae spp. used in this study and comparison with previous studies

\begin{tabular}{|c|c|c|c|c|c|}
\hline Species & Isolate $^{w}$ & Conidial size $(\mu \mathbf{m})(\mathbf{L} \times \mathbf{W})^{\mathbf{x}}$ & Mean \pm SD $(\mu \mathrm{m})(\mathbf{L} \times \mathbf{W})^{\mathbf{y}}$ & $\mathbf{L} / \mathbf{W}^{\mathbf{z}}$ & Source of data \\
\hline Diplodia olivarum & BAL-35 & $(20.5-) 22-27(-28) \times(10-) 10.5-13.5(-14.5)$ & $24.2 \pm 1.5 \times 12.3 \pm 1$ & 2 & This study \\
\hline D. olivarum & BAL-39 & $(21.5-) 22.5-28(-28.5) \times(10.5-) 11-13(-14.5)$ & $24.5 \pm 1.6 \times 12.5 \pm 1$ & 2 & This study \\
\hline D. olivarum & BAL-43 & $(20.5-) 22-27.5(-28.5) \times(9.5-) 9-12.5(-14)$ & $24 \pm 1.5 \times 12.1 \pm 1$ & 2 & This study \\
\hline D. olivarum & Type & $(21.5-) 22-27.5(-28.5) \times(10-) 11-13.5(-14.5)$ & $24.4 \pm 1.6 \times 12.4 \pm 1$ & 2 & Lazzizera et al. (2008a) \\
\hline D. seriata & BAL-10 & $(19.5-) 20-26.5(-27) \times(10.5-) 11.5-14(-15)$ & $23.6 \pm 1.4 \times 11.9 \pm 0.8$ & 2 & This study \\
\hline D. seriata & BAL-16 & $(20-) 22-26.5(-28) \times(11-) 11.5-14.5(-15.5)$ & $24 \pm 1.2 \times 12.6 \pm 1$ & 1.9 & This study \\
\hline D. seriata & BAL-45 & $(19.5-) 21-26.5(-27.5) \times(10.5-) 11.5-14(-15)$ & $24.5 \pm 1.2 \times 12.7 \pm 1$ & 1.9 & This study \\
\hline D. seriata & Type & $(21.5-) 22-27(-28) \times(11-) 11.5-14.5(-15.5)$ & $24.9 \pm 1.9 \times 12.9 \pm 1.1$ & 1.9 & Phillips et al. (2007) \\
\hline Neofusicoccum luteum & BAL-30 & $(15.5-) 18.5-23(-24) \times(4.5-) 5-6(-7.5)$ & $19.9 \pm 1.6 \times 5.6 \pm 0.5$ & 3.6 & This study \\
\hline N. luteum & BAL-33 & $(15-) 17-21.5(-23) \times(4-) 5-6(-7.5)$ & $19.6 \pm 1.8 \times 5.6 \pm 0.5$ & 3.5 & This study \\
\hline N. luteum & BAL-34 & $(15-) 17.5-22(-23.5) \times(4-) 5-6.5(-7.5)$ & $19.5 \pm 1.7 \times 5.7 \pm 0.5$ & 3.4 & This study \\
\hline N. luteum & Type & $(15-) 18-22.5(-24) \times 4.5-6(-7.5)$ & $19.7 \pm 1.8 \times 5.6 \pm 0.6$ & 3.6 & Phillips et al. (2002) \\
\hline N. mediterraneum & BAL-3 & $(19.5-) 22.5-26(-27.5) \times 5.5-6.5$ & $23.9 \pm 2.8 \times 4.8 \pm 0.7$ & 5 & This study \\
\hline N. mediterraneum & BAL-15 & $(19-) 21.5-26(-27) \times(5-) 6-(-6.5)$ & $24 \pm 2.2 \times 4.9 \pm 0.5$ & 4.9 & This study \\
\hline N. mediterraneum & BAL-37 & $(18.5-) 20.5-25.5(-26.5) \times(5-) 5.5-(-6.5)$ & $23.8 \pm 2.4 \times 4.8 \pm 0.5$ & 4.9 & This study \\
\hline N. mediterraneum & Type & $(19-) 22-26(-27) \times(5.5-) 6(-6.5)$ & $24 \times 6$ & 5 & Crous et al. (2007) \\
\hline N. parvum & BAL-7 & $(14.5-) 16-20(-20.5) \times(5-) 5.5-6.5(-7)$ & $16.8 \pm 0.8 \times 5.8 \pm 0.8$ & 2.9 & This study \\
\hline N. parvum & BAL-41 & $(14.5-) 16.5-20.5(-21.5) \times(4.5-) 5-6(-6.5)$ & $18.3 \pm 1.4 \times 5.5 \pm 0.8$ & 3.3 & This study \\
\hline N. parvum & BAL-42 & $(13.5-) 16-20(-22.5) \times(4.5-) 5.5-6(-6.5)$ & $17.9 \pm 1.3 \times 5.6 \pm 0.7$ & 3.2 & This study \\
\hline N. parvum & Type & $(12-) 15-19(-24) \times 4-6$ & $16.9 \times 5.4$ & 3.1 & Slippers et al. (2004) \\
\hline
\end{tabular}

${ }^{\mathrm{w}}$ Type $=$ isolates for measurements are ex-type of from samples that have been linked to type material of the species. The information of the type is in boldface.

${ }^{\mathrm{x}} \mathrm{L} \times \mathrm{W}=$ length by width; minimum-(average - standard deviation $[\mathrm{SD}]$ )-average $\pm \mathrm{SD}$ )-maximum.

${ }^{y} \mathrm{~L} \times \mathrm{W}=$ length by width.

${ }^{\mathrm{z}} \mathrm{L} / \mathrm{W}=$ average length/average width. 
oblong or oval, and aseptate or one septate; and D. seriata, which showed conidia that were aseptate, thick-walled, and hyaline but became brown before they were released from conidiogenous cells into the pycnidia.

Effect of temperature on mycelial growth. Data from both experiments were averaged because an LSD test showed no significant differences of the mycelial growth between experiments $(P=0.6834)$. Most of the isolates studied grew on PDA at 10 to $35^{\circ} \mathrm{C}$, while some of them failed to grow at $5^{\circ} \mathrm{C}(D$. olivarum isolates BAL-35 and BAL-39, N. luteum isolates BAL-30 and BAL-34, and N. parvum isolates BAL-7 and BAL-41). Optimal temperatures for mycelial growth ranged from 20.4 to $23.7^{\circ} \mathrm{C}$. Significant differences were found in the optimal temperature between $D$. seriata isolate BAL-45 and $D$. olivarum isolates $(P<0.01)$ but it was not possible to differentiate the remaining isolates statistically, because of the extensive overlap for the optimal temperature among them (Table 4). According to the Kruskal-Wallis test, maximum growth rates of isolates differed significantly $(P<$ 0.01 ). For all isolates, the relationship between growth rate (millimeters per day) and temperature was best described by a second-degree polynomial $\left(Y=a \mathrm{~T}^{2}+b \mathrm{~T}+c \mathrm{~T}\right)$. The three regression coefficients were highly significant in all cases $(P<0.01)$. The coefficient of determination $\left(R^{2}\right)$ ranged from 0.721 to 0.899 . In general, isolates were separated into three groups: $D$. seriata (three isolates), $N$. luteum isolate BAL-30, and $N$. parvum isolate BAL-42, whose maximum growth rate was $\geq 14.3 \mathrm{~mm} /$ day; a second group comprising $D$. olivarum (three isolates), $N$. luteum isolates BAL-33 and BAL-34, N. mediterraneum isolates BAL-3 and BAL-37, and N. parvum isolates BAL-7 and BAL41 , whose maximum growth rate was $<13.2 \mathrm{~mm} /$ day; and a third group comprising only $N$. mediterraneum isolate $\mathrm{BAL}-15$, whose maximum growth rate was $8.2 \mathrm{~mm} /$ day.

Phylogenetic analyses. In total, 45 isolates were sequenced to confirm their identity. PCR amplifications of the ITS and EF1- $\alpha$ regions gave products of approximately 0.6 and $0.8 \mathrm{~kb}$, respectively. These new sequences were deposited in GenBank (Table 1). The topology of the trees of individual gene regions (ITS or EF1- $\alpha$ ) was consistent between them, with no major conflicts; thus, the two loci were combined.

The combined ITS and EF1- $\alpha$ dataset of Botryosphaeriaceae spp. included 85 taxa (83 ingroups and 2 outgroups) and contained 661 characters (including alignment gaps). The combined alignment consisted of 454 characters from ITS and 207 from EF. In the phylogenetic analysis, two main clades were resolved within the ingroup (Fig. 1). In clade 1, the isolates obtained in this study clustered with three previously described Neofusicoccum spp.: N. luteum (10 isolates),
$N$. mediterraneum (9 isolates), and $N$. parvum (5 isolates). In the clade 2 , the isolates obtained in this study clustered with two previously described Diplodia spp.: D. olivarum (10 isolates) and D. seriata (11 isolates).

Pathogenicity tests. All the Botryosphaeriaceae isolates produced cankers with gum exudations 3 to 4 weeks after inoculation of the almond stems. Fruiting bodies were only observed on some of the stems inoculated with $N$. luteum. There were significant differences between the results of the two experiments (2013 and 2014; $P<$ $0.01)$; therefore, the data were analyzed separately. Because, in both years, the cultivar-fungal species interaction was significant (2013: $F=4.55, \mathrm{df}=12, P=<0.001 ; 2014: F=2.13, \mathrm{df}=12, P=0.0215)$, the virulence of the isolates was independently evaluated for each almond cultivar. Mean lengths of the extent of vascular discolorations caused by Botryosphaeriaceae spp. isolates on inoculated 2-year-old almond wood of four cultivars (Pons, Vivot, Jordi, and Ferragnes) during 2013 and 2014 are shown in Figure 2.

In 2013, the Neofusicoccum spp. were the most virulent in all almond cultivars and significantly differed $(P<0.05)$ in the lesion length produced on almond branches from the control treatment (Fig. 2). N. luteum showed the longest mean lesion lengths that were significantly different $(P<0.05)$ from those caused by any other Botryosphaeriaceae sp. in all cultivars. Diplodia spp. were less virulent than Neofusicoccum spp. in all cultivars, showing shorter mean lesion lengths. $D$. seriata was more virulent than $D$. olivarum but only significantly different $(P<0.05)$ from the control in Jordi and Vivot. In general, Jordi was less sensitive to fungal infection.

During the 2014 experiment, some of the trees of Jordi and Vivot died, probably due to heavy pruning that was done on them in order to remove any sign of internal injury from the inoculations performed in 2013. Therefore, in these cultivars, there were not enough trees for the statistical study in inoculations of Jordi with $D$. seriata and Vivot with D. olivarum, D. seriata, and N. parvum (Fig. 2). In 2014, all the Neofusicoccum spp. were more virulent than Diplodia spp. but, in contrast with the 2013 experiment, $N$. mediterraneum and $N$. parvum showed longer mean lesion lengths than $N$. luteum, which were significantly different $(P<0.05)$ from the controls in Ferragnes, Jordi, and Pons. In Vivot, only $N$. mediterraneum was significantly different $(P<0.05)$ from the control. Diplodia spp. were less virulent than Neofusicoccum spp. in all cultivars but never significantly different from the controls.

Each fungal pathogen was successfully reisolated (100\%) from inoculated plants on MEAS, thereby confirming Koch's postulates. No Botryosphaeriaceae spp. were isolated from control plants.

Table 4. Temperature-growth relationship for Botryosphaeriaceae isolates ${ }^{\mathrm{w}}$

\begin{tabular}{|c|c|c|c|c|c|c|c|}
\hline \multirow[b]{2}{*}{ Species } & \multirow[b]{2}{*}{ Isolate } & \multicolumn{4}{|c|}{ Adjusted model $^{x}$} & \multirow[b]{2}{*}{ Temperature $\left({ }^{\circ} \mathrm{C}\right)^{\mathrm{y}}$} & \multirow[b]{2}{*}{ Growth $(\mathrm{mm} / \text { day })^{\mathbf{z}}$} \\
\hline & & $R^{2}$ & $a$ & $b$ & $c$ & & \\
\hline Diplodia olivarum & BAL-35 & 0.859 & -0.0559 & 2.3406 & -11.632 & $20.9 \mathrm{~b}$ & $12.9 \mathrm{bc}$ \\
\hline D. olivarum & BAL-39 & 0.899 & -0.0561 & 2.2871 & -11.021 & $20.4 \mathrm{~b}$ & $12.3 \mathrm{bc}$ \\
\hline D. olivarum & BAL-43 & 0.879 & -0.0556 & 2.3022 & -11.981 & $20.7 \mathrm{~b}$ & $11.8 \mathrm{bc}$ \\
\hline Diplodia seriata & BAL-10 & 0.801 & -0.0455 & 2.1554 & -11.244 & $23.7 \mathrm{ab}$ & $14.3 \mathrm{ab}$ \\
\hline D. seriata & BAL-16 & 0.905 & -0.0515 & 2.3423 & -11.431 & $22.7 \mathrm{ab}$ & $15.2 \mathrm{ab}$ \\
\hline D. seriata & BAL-45 & 0.854 & -0.0537 & 2.6658 & -14.929 & $24.8 \mathrm{a}$ & $18.1 \mathrm{a}$ \\
\hline Neofusicoccum luteum & BAL-30 & 0.721 & -0.0521 & 2.4530 & -13.370 & $23.5 \mathrm{ab}$ & $15.5 \mathrm{ab}$ \\
\hline N. luteum & BAL-33 & 0.795 & -0.0503 & 2.2404 & -11.932 & $22.3 \mathrm{ab}$ & $13.0 \mathrm{bc}$ \\
\hline N. luteum & BAL-34 & 0.737 & -0.0474 & 2.0881 & -12.631 & $22.0 \mathrm{ab}$ & $10.4 \mathrm{bc}$ \\
\hline N. mediterraneum & BAL-3 & 0.731 & -0.0526 & 2.3763 & -13.667 & $22.6 \mathrm{ab}$ & $13.2 \mathrm{bc}$ \\
\hline N. mediterraneum & BAL-15 & 0.790 & -0.0332 & 1.4680 & -8.0322 & $22.1 \mathrm{ab}$ & $8.2 \mathrm{c}$ \\
\hline N. mediterraneum & BAL-37 & 0.791 & -0.0455 & 2.0112 & -10.351 & $22.1 \mathrm{ab}$ & $11.9 \mathrm{bc}$ \\
\hline N. parvum & BAL-7 & 0.865 & -0.0420 & 1.8900 & -10.613 & $22.5 \mathrm{ab}$ & $10.6 \mathrm{bc}$ \\
\hline N. parvum & BAL-41 & 0.731 & -0.0498 & 2.3233 & -14.433 & $23.3 \mathrm{ab}$ & $12.7 \mathrm{bc}$ \\
\hline N. parvum & BAL-42 & 0.823 & -0.0525 & 2.4201 & -13.320 & $22.8 \mathrm{ab}$ & $14.6 \mathrm{~b}$ \\
\hline
\end{tabular}

${ }^{\mathrm{w}}$ Data are the average of 12 replicates for each isolate. For each column, means with the same letter are not significantly different $(P=0.05)$ according to the Kruskal-Wallis test and the Dunn's test for multiple comparison of mean ranks.

${ }^{\mathrm{x}}$ Mycelial growth on potato dextrose agar at 5 to $35^{\circ} \mathrm{C}$ was adjusted to a second-degree polynomial model: $Y=a \mathrm{~T}^{2}+b \mathrm{~T}+c$, in which $Y=$ mycelial growth $\left(\mathrm{mm} /\right.$ day); $a, b$, and $c$ are the regression coefficients; and $R^{2}=$ coefficient of determination.

y Optimal temperature estimated by the adjusted model.

${ }^{\mathrm{z}}$ Maximum growth rate estimated by the adjusted model. 


\section{Discussion}

This study is the first comprehensive effort to characterize species of Botryosphaeriaceae associated with almond trees in Spain. Observed symptoms caused by these pathogens were similar to those described on other hosts such as grapevine or fruit trees: internal V-shaped wood necrosis, cankers eventually bleeding gum, wood decay, and dead shoots (Adesemoye et al. 2014; Damm et al. 2007; González-Domínguez et al. in press; Luque et al. 2009; Moral et al. 2010). Combined results of phenotypical characteristics and phylogenetic analyses of the nuclear ribosomal DNA-ITS region and EF1- $\alpha$ gene allowed the identification of five species of Botryosphaeriaceae belonging to two genera. These included $D$. seriata,

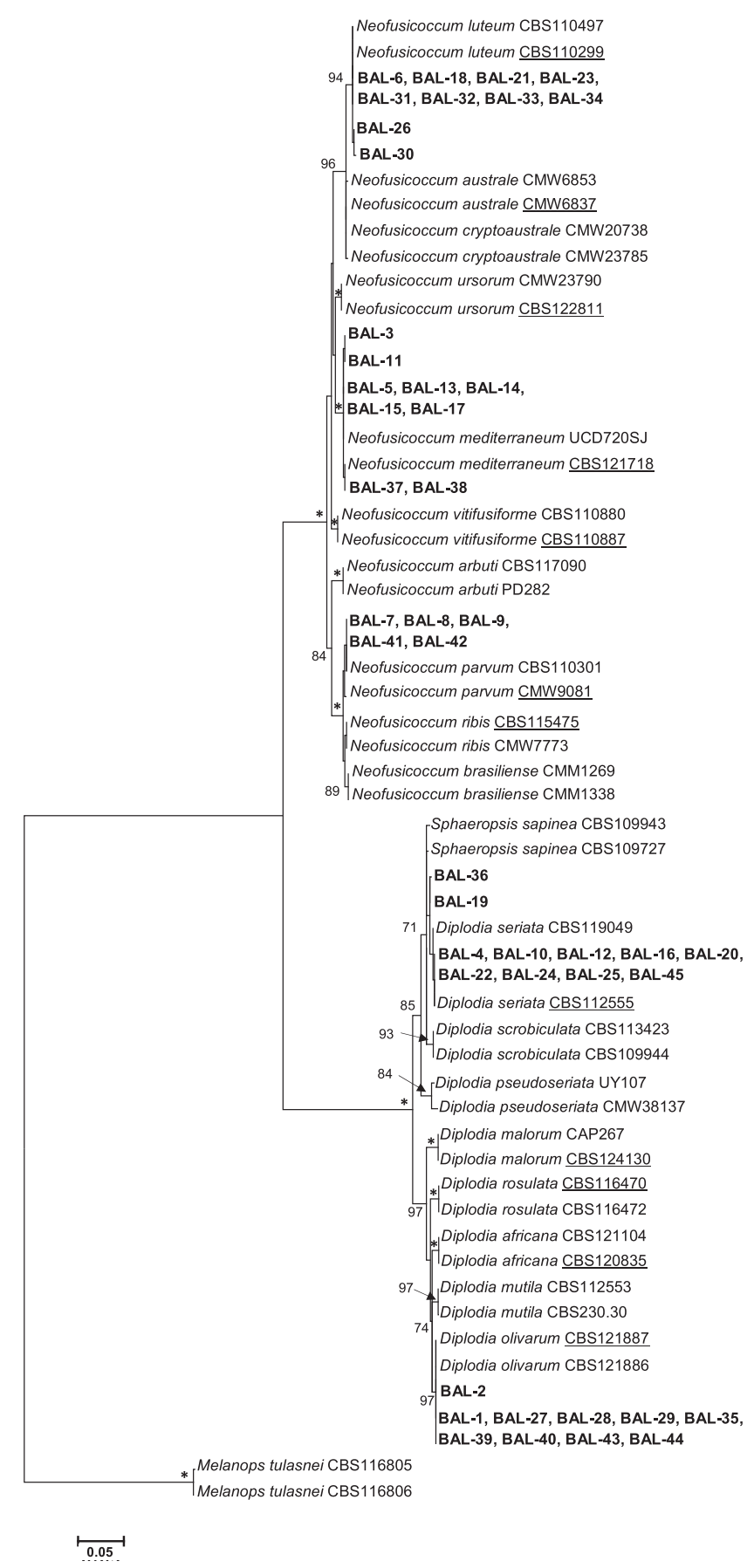

Fig. 1. Single tree resulting from maximum-likelihood analysis generated from the combined analysis of internal transcribed spacer and elongation factor 1- $\alpha$ sequence data from species of Neofusicoccum and Diplodia. Bootstrap values are indicated at each node. Asterisks $\left(^{*}\right)$ represent bootstrap values from 99 to $100 \%$ and values less than $70 \%$ are not shown. The tree was rooted to Melanops tulasnei. Isolates from almond are in bold. Ex-type isolates are underlined.
D. olivarum, $N$. mediterraneum, $N$. luteum, and $N$. parvum. First reports from almond in Spain included N. mediterraneum and N. luteum.

Morphological features were previously used partially to characterize Botryosphaeriaceae spp. isolated from grapevine (Martos 2008) and olive (Moral et al. 2010) in Spain. In our study, colony growth characteristics, culture, and conidial morphology of the almond fungi were determined. These phenotypical characteristics offered valuable information to support the species identification that was confirmed by DNA sequence comparisons. Colony and conidial morphology were the most helpful features that facilitated the differentiation among the three Neofusicoccum spp. collected from almond trees, in agreement with previous literature (Adesemoye et al. 2014; Phillips et al. 2013). However, results of the morphological comparison revealed that there is an overlap between $D$. olivarum and $D$. seriata in conidia length and width, although $D$. seriata isolates grew much faster than those of D. olivarum. The optimal growth temperature was similar among all the species found in this study, with the exception of D. olivarum isolates that showed optimal growth temperatures below $24^{\circ} \mathrm{C}$. The only previous approach to determine the exact optimal growth temperature of Botryosphaeriaceae spp. by using regression curves was carried out by Moral et al. (2010). Our study revealed that isolates collected from almond trees in Spain showed lower optimal growth temperatures than those obtained from olive trees in California and Spain (Moral et al. 2010).

D. seriata was one of the most frequently isolated Botryosphaeriaceae sp. in this study. This pathogen is known to occur on a wide range of hosts (Punithalingam and Waller 1973). To cite an example, 264 hosts were listed by Farr et al. (2008) under its former name of B. obtusa. Our results are in agreement with those obtained by Damm et al. (2007), who found a high incidence of $D$. seriata in apricot, nectarine, peach, and Japanese plum in South Africa, and by Sessa et al. (in press) from apple, pear, and peach in Uruguay. D. seriata was also the prevalent species in studies carried out in South Africa on pome (Cloete et al. 2011; Slippers et al. 2007) and stone fruit trees (Slippers et al. 2007), and in Spain on loquat (González-Domínguez et al. in press). In almond, our results differ with those published by Inderbitzin et al. (2010), who found $D$. seriata to be a minor pathogen associated with almond trees in California. D. seriata is one of the most common species associated with Botryosphaeria dieback of grapevine (Úrbez-Torres 2011), and it is known to cause severe diseases in some host plants such as olive in California (ÚrbezTorres et al. 2013), Croatia (Kaliterna et al. 2012), and Spain (Moral et al. 2008).

D. olivarum was first reported in Spain in a previous study on almond trees carried out by Gramaje et al. (2012). This species has been also isolated from diseased olive drupes (Lazzizera et al. 2008a) and carob trees (Ceratonia siliqua) showing foliage reddening, cankers and branch dieback (Granata et al. 2011) in Italy. This species was recently associated with Botryosphaeria dieback of grapevine in Italy (Linaldeddu et al. 2015).

The high incidence of $N$. mediterraneum agrees with the results of Inderbitzin et al. (2010) from almond and other hosts in California. This species has been associated with grapevine decline syndrome in California (Úrbez-Torres et al. 2010) and Spain (Martín et al. 2011; Pintos Varela et al. 2011a), and has also been isolated from rootstock mother plants in several nurseries in Spain (Aroca et al. 2010). Lazzizera et al. (2008b) found this species causing drupe rot of olive in Italy, although with low incidence compared with other Botryosphaeriaceae spp. N. mediterraneum has been reported to cause shoot cankers and dieback of olive and pistachio in California and Spain (Moral et al. 2010), as well as associated with diseased walnut (Trouillas et al. 2010) and pomegranate (Morgan and Michailides 2012) in California, and with postharvest fruit rot of persimmon (Palou et al. 2013) and branch canker and dieback of loquat (González-Domínguez et al. in press) in Spain.

$N$. luteum was also frequently isolated from the almond trees studied here. This species has been associated with grapevine decline syndrome worldwide (Chebil et al. 2014; Luque et al. 2009; Úrbez-Torres and Gubler 2009; van Niekerk et al. 2004). N. luteum was first reported as Fusicoccum luteum in kiwi, pear, and apple in 
New Zealand (Pennycook and Samuels 1985), and has been recently isolated from olive (Sergeeva et al. 2009; Úrbez-Torres et al. 2013), avocado (McDonald et al. 2009), and citrus (Adesemoye et al. 2014) in California. In Spain, N. luteum has been isolated from Rhododendron spp. plants exhibiting leaf spots, cankers, and dieback of shoots and branches (Pintos Varela et al. 2011b) and associated with postharvest fruit rot of persimmon (Palou et al. 2013).

$N$. parvum was also isolated from many field sites. This species is a common pathogen of pome and stone fruit trees worldwide (Slippers et al. 2007), and was recently reported affecting almond trees in California (Inderbitzin et al. 2010). It is also frequently associated with Botryosphaeria dieback in grapevine (Úrbez-Torres 2011). Recent reports of $N$. parvum include diseased apple, pear, and peach (Sessa et al. in press), blueberry bushes (Castillo et al. 2013; Choi et al. 2012; Koike et al. 2014; Wright et al. 2011), citrus (Adesemoye and Eskalen 2011), peach (Thomidis et al. 2011), and avocado, in which a range of symptoms appear such as black spots on fruit (Molina-Gayosso et al. 2012), tree decay (Zea-Bonilla et al. 2007), and branch cankers (McDonald et al. 2009). In Spain, this species was also isolated from English walnut (Juglans regia) and Japanese plum trees (Moral et al. 2010), and from branch cankers and dieback of loquat (González-Domínguez et al. in press).

Although there were differences in the pathogenicity tests between years, probably due to different weather conditions and other environmental factors that cannot be controlled in an orchard, in general, our results revealed that Neofusicoccum spp. were the most virulent to the tested almond cultivars. Virulence tests on almond in California (Inderbitzin et al. 2010) showed that $N$. nonquaesitum and N. parvum were the most virulent species. Previous research showed that $N$. luteum and $N$. parvum are highly virulent on avocado (McDonald et al. 2009) and citrus (Adesemoye et al. 2014) in California and on grapevine in California (Úrbez-Torres and Gubler 2009), New Zealand (Billones-Baaijens et al. 2014), and Spain (Luque et al. 2009). Inoculation indicated that $N$. mediterraneum is intermediately to highly virulent to almond (Inderbitzin et al. 2010) and English walnut (Chen et al. 2014) in California, grapevine in California (Úrbez-Torres et al. 2010) and Spain (Martín et al. 2011; Pintos Varela et al. 2011a), and olive in California and Spain (Moral et al. 2010).

Inoculations showed that $D$. seriata is intermediately virulent to almond cultivars between highly and less virulent fungal species.

2013

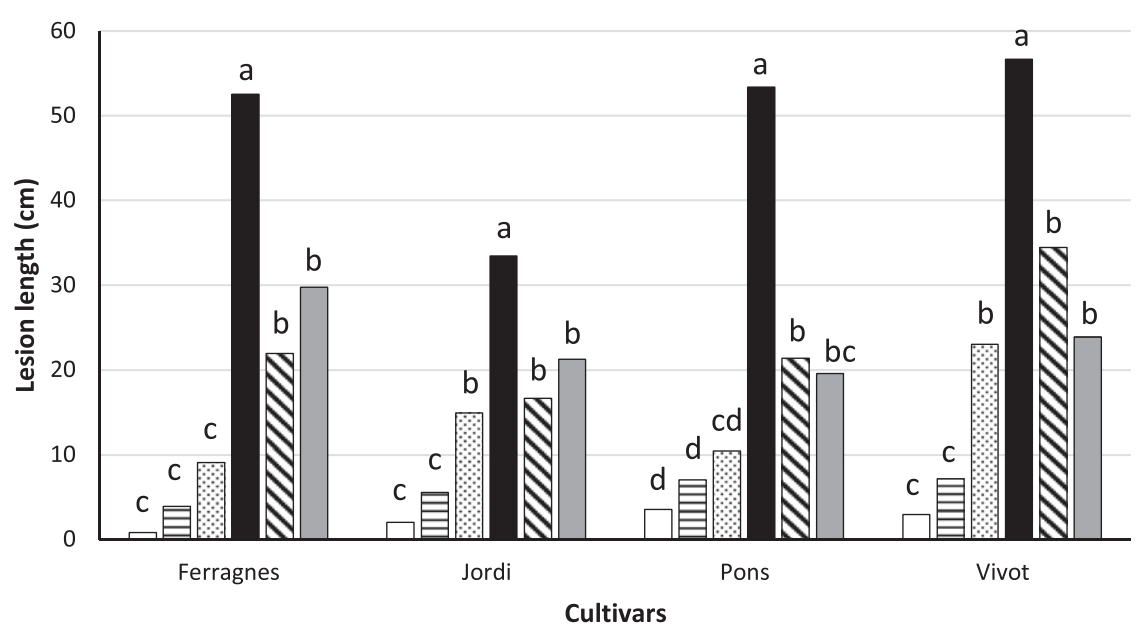

2014

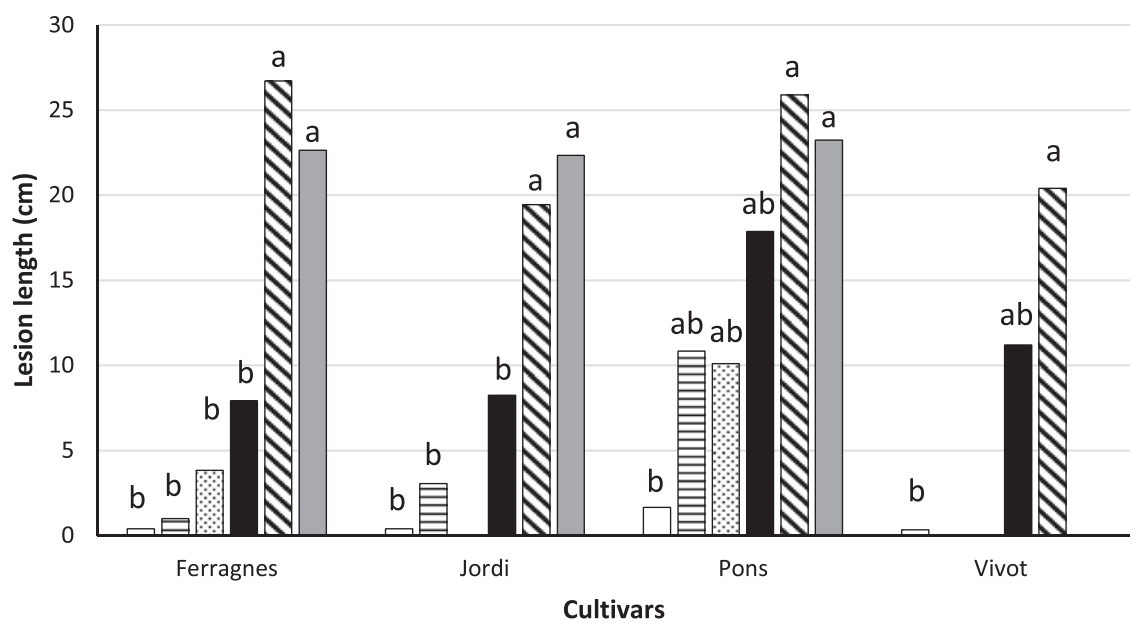

$\square$ Control $\boxminus \mathrm{D}$. olivarum $\quad \mathrm{D}$. seriata $\quad \mathbf{N}$. luteum $\mathbf{\Delta N}$. mediterraneum $\quad \square \mathrm{N}$. parvum

Fig. 2. Mean lesion length (in centimeters) caused by Botryosphaeriaceae spp. in four almond cultivars 9 months after inoculation. Experiments were conducted in 2013 and 2014. Values are the means of 12 inoculated trees per fungus (four repetitions with three replicates). In each cultivar, means followed by the same letter are not significantly different using Tukey's honestly significant difference test $(P<0.05)$. In 2014, there were no data for Diplodia seriata in Jordi and for $D$. olivarum, $D$. seriata, and N. parvum in Vivot. 
These results agree with those obtained by Inderbitzin et al. (2010) on almond in California. In other hosts such as grapevine, the pathogenic status of $D$. seriata remains unclear and is still a matter of discussion among researchers (Elena et al. 2015; Úrbez-Torres 2011). Our results indicate that $D$. olivarum can be considered as weakly pathogenic on almond in Spain. This fungus was previously showed to be pathogenic on 2-year-old carob trees in Italy (Granata et al. 2011).

In conclusion, our results and references in literature indicate that none of the species of Botryosphaeriaceae found on almond are host specific but also occur on other hosts such as deciduous fruit and nut trees, thus endangering the productivity and longevity of orchards in Spain as well as in other countries (Gramaje et al. 2016). For example, species of Botryosphaeriaceae seriously impede the competitiveness and sustainability of the wine and table grape industry worldwide (Úrbez-Torres 2011). Grapevines are frequently cultivated in close proximity to almond orchards in Spain and, in addition, grapevines are often established on soils previously cultivated to almond trees. At present, it is unknown to what extent these trees act as alternative hosts and whether they act as inoculum sources of grapevine trunk disease pathogens. This information is vital for our understanding of the disease cycles and management strategies for the different trunk diseases on pome and stone fruits, nut crops, and olive trees.

\section{Acknowledgments}

D. Gramaje was supported by the DOC-INIA program from the National Institute for Agronomic Research (INIA), co-funded by the European Social Fund. We thank the researchers of ENOCIDA group for providing the incubators for the temperature growth assay and $\mathrm{J}$. Moral for statistical advice.

\section{Literature Cited}

Adesemoye, A. O., and Eskalen, A. 2011. First report of Spencermartinsia viticola, Neofusicoccum australe, and N. parvum causing branch canker of citrus in California. Plant Dis. 95:770.

Adesemoye, A. O., Mayorquin, J. S., Wang, D. H., Twizeyimana, M., Lynch, S. C., and Eskalen, A. 2014. Identification of species of Botryosphaeriaceae causing bot gummosis in citrus in California. Plant Dis. 98:55-61.

Armengol, J., Gramaje, D., Pérez-Sierra, A., Landeras, E., Alzugaray, R., Martos, S., and Luque, J. 2008. First report of canker disease caused by Neofusicoccum australe on eucalyptus and pistachio in Spain. Plant Dis. 92:980.

Armengol, J., Vicent, A., Torn, L., García-Figueres, F., and García-Jiménez, J. 2001. Fungi associated with esca and grapevine declines in Spain: A threeyear survey. Phytopathol. Mediterr. 40:S325-S329.

Aroca, A., Gramaje, D., Armengol, J., García-Jiménez, J., and Raposo, R. 2010. Evaluation of grapevine nursery process as a source of Phaeoacremonium spp. and Phaeomoniella chlamydospora and occurrence of trunk disease pathogens in rootstock mother vines in Spain. Eur. J. Plant Pathol. 126:165-174.

Billones-Baaijens, R., Jones, E. E., Ridgway, H. J., and Jaspers, M. V. 2014. Susceptibility of common rootstock and scion grapevine varieties in New Zealand to Botryosphaeriaceae species. Australas. Plant Pathol. 43:25-31.

Box, G. E. P., Hunter, W. G., and Hunter, J. S. 1978. Statistics for Experimenters: An Introduction to Design, Data Analysis, and Model Building. John Wiley and Sons, New York.

Brown, E. A., and Britton, K. O. 1986. Botryosphaeria diseases of apples and peach in the southeastern United States. Plant Dis. 70:480-484.

Castillo, S., Borrero, C., Castaño, R., Rodriguez, A., and Aviles, M. 2013. Fungal first report of Canker Disease caused by Neofusicoccum parvum and N. australe on Blueberry bushes in Spain. Plant Dis. 97:1112.

Chebil, S., Fersi, R., Yakoub, A., Chenenaoui, S., Chattaoui, M., Melki, I., Zemni, H., Rhouma, A., Durante, G., Zacchi, E., and Mliki, A. 2014. First report of Botryosphaeria dothidea, Diplodia seriata, and Neofusicoccum luteum associated with canker and dieback of grapevines in Tunisia. Plant Dis. 98:420.

Chen, S. F., Morgan, D. P., Hasey, J. K., Anderson, K., and Michailides, T. J. 2014. Phylogeny, morphology, distribution, and pathogenicity of Botryosphaeriaceae and Diaporthaceae from English walnut in California. Plant Dis. 98:636-652.

Choi, I.-Y., Sharma, P. K., and Cheong, S.-S. 2012. First report of Neofusicoccum parvum associated with bark dieback of blueberry in Korea. Plant Pathol. J. 28:217.

Cloete, M., Fourie, P. H., Damm, U., Crous, P. W., and Mostert, L. 2011. Fungi associated with die-back symptoms of apple and pear trees with a special reference to grapevine trunk disease pathogens. Phytopathol. Mediterr. 50: S176-S190.

Crous, P. W., Groenewald, J. Z., Wingfield, M. J., and Phillips, A. J. L. 2007. Neofusicoccum mediterraneum. Fungal Planet 19. CBS-KNAW Fungal Biodiversity Centre, Utrecht, The Netherlands.

Damm, U., Crous, P. W., and Fourie, P. H. 2007. Botryosphaeriaceae as potential pathogens of Prunus species in South Africa, with descriptions of Diplodia africana and Lasiodiplodia plurivora sp. nov. Mycologia 99:664-680.
Elena, G., García-Figueres, F., Reigada, S., and Luque, J. 2015. Intraspecific variation in Diplodia seriata isolates occurring on grapevines in Spain. Plant Pathol. 64:680-689.

FAOSTAT. 2013. Food and Agriculture Organization of the United NationsStatistical Division. Online publication. http://www.fao.org/economic/ess/en/

Farr, D. F., Rossman, A. Y., Palm, M. E., and McCray, E. B. 2008. Fungal Databases. Online publication. Systematic Botany \& Mycology Laboratory, USDA-ARS. http://nt.ars-grin.gov/fungaldatabases/

Gardes, M., and Bruns, T. D. 1993. ITS primers with enhanced specificity for basidiomycetes - application to the identification of mycorrhizae and rusts. Mol. Ecol. 2:113-118.

González-Domínguez, E., Alves, A., León, M., and Armengol, J. Characterization of Botryosphaeriaceae species associated with diseased loquat (Eriobotrya japonica) in Spain. Plant Pathol. In press. doi:10.1111/ppa.12556

Gramaje, D., Agustí-Brisach, C., Pérez-Sierra, A., Moralejo, E., Olmo, D., Mostert, L., Damm, U., and Armengol, J. 2012. Fungal trunk pathogens associated with wood decay of almond trees on Mallorca (Spain). Persoonia 28:1-13.

Gramaje, D., Baumgartner, K., Halleen, F., Mostert, L., Sosnowski, M. R., ÚrbezTorres, J. R., and Armengol, J. 2016. Fungal trunk diseases: A problem beyond grapevines? Plant Pathol. 65:355-356.

Granata, G., Faedda, R., and Sidoti, A. 2011. First report of canker disease caused by Diplodia olivarum on carob tree in Italy. Plant Dis. 95:776.

Inderbitzin, P., Bostock, R. M., Trouillas, F. P., and Michailides, T. J. 2010. A six locus phylogeny reveals high species diversity in Botryosphaeriaceae from California almond. Mycologia 102:1350-1368.

INE. 2014. Spanish Statistical Office. Online publication. http://www.ines.es

Jacobs, K., Bergdahl, D. R., Wingfield, M. J., Halik, S., Seifert, K. A., Bright, D. E., and Wingfield, B. D. 2004. Leptographium wingfieldii introduced into North America and found associated with exotic Tomicus piniperda and native bark beetles. Mycol. Res. 108:411-418.

Kaliterna, J., Milicevic, T., Ivic, D., Bencic, D., and Mesic, A. 2012. First report of Diplodia seriata as causal agent of olive dieback in Croatia. Plant Dis. 96:290.

Koike, S. T., Rooney-Latham, S., and Wright, A. F. 2014. First report of stem blight of blueberry in California caused by Neofusicoccum parvum. Plant Dis. 98:1280.

Kumar, S., Stecher, G., and Tamura, K. 2016. MEGA 7: Molecular Evolutionary Genetics Analysis version 7.0 for bigger datasets. Mol. Biol. Evol. 33: $1870-1874$

Lazzizera, C., Frisullo, S., Alves, A., Lopes, J., and Phillips, A. J. L. 2008a Phylogeny and morphology of Diplodia species on olives in southern Italy and description of Diplodia olivarum sp. nov. Fungal Divers. 31:63-71.

Lazzizera, C., Frisullo, S., Alves, A., and Phillips, A. J. L. 2008b. Morphology, phylogeny and pathogenicity of Botryosphaeria and Neofusicoccum species associated with drupe rot in olives in southern Italy. Plant Pathol. 57:948-956.

Linaldeddu, B. T., Deidda, A., Scanu, B., Franceschini, A., Serra, S., BerrafTebbal, A., Boutiti, M. Z., Ben Jamaa, M. L., and Phillips, A. J. L. 2015 Diversity of Botryosphaeriaceae species associated with grapevine and other woody hosts in Italy, Algeria and Tunisia, with descriptions of Lasiodiplodia exigua and Lasiodiplodia mediterranea sp. nov. Fungal Divers. 71:201-214.

Luque, J., Martos, S., Aroca, A., Raposo, R., and García-Figueres, F. 2009. Symptoms and fungi associated with declining mature grapevine in northeast Spain. J. Plant Pathol. 91:381-390.

Martín, M. T., Martín, L., and Cuesta, M. J. 2011. First report of Neofusicoccum mediterraneum and $N$. australe causing decay in Vitis vinifera in Castilla y Leon, Spain. Plant Dis. 95:876.

Martos, S. 2008. El decaimento de la vid. Enfermedades de la madera relacionadas con hongos de la familia Botryosphaeriaceae. Ph.D. dissertation, Publ. No. ISBN 9788469165904, Universidad Autònoma de Barcelona, Spain.

McDonald, V., Lynch, S., and Eskalen, A. 2009. First report of Neofusicoccum australe, $N$. luteum, and $N$. parvum associated with avocado branch canker in California. Plant Dis. 93:967.

Molina-Gayosso, E., Silva-Rojas, H. V., García-Morales, S., and Avila-Quezada, G. 2012. First report of black spots on avocado fruits caused by Neofusicoccum parvum in Mexico. Plant Dis. 96:287.

Moral, J., Luque, F., and Trapero, A. 2008. First report of Diplodia seriata, the anamorph of "Botryosphaeria" obtusa, causing fruit rot of olive in Spain. Plant Dis. 92:311.

Moral, J., Muñoz-Díez, C., González, N., Trapero, A., and Michailides, T. J. 2010 Characterization and pathogenicity of Botryosphaeriaceae species collected from olives and other hosts in Spain and California. Phytopathology 100: 1340-1351.

Morgan, D. P., and Michailides, T. J. 2012. Neofusicoccum mediterraneum causing cankers and Diplodia mutila and Diplodia seriata isolated from pomegranate (Punica granatum) in California. (Abstr.) Phytopathology 102:S4.83.

Nishi, S., Kendall, C. W. C., Gascoyne, A. M., Bazinet, R. O., Bashyam, B., Lapsley, K. G., Augustin, L. S. A., Sievenpiper, J. L., and Jenkins, D. J. A 2014. Effect of almond consumption on the serum fatty acid profile: A doseresponse study. Br. J. Nutr. 112:1137-1146.

Palou, J., Montesinos-Herreo, C., and Besada, C. 2013. Postharvest fruit rot of Persimmon (Diospyros kaki) in Spain caused by Lasiodiplodia theobromae and Neofusicoccum spp. J. Phytopathol. 161:625-631. 
Pennycook, S. R., and Samuels, G. J. 1985. Botryosphaeria and Fusicoccum species associated with ripe fruit rot of Actinidia deliciosa (Kiwifruit) in New Zealand. Mycotaxon 24:445-458.

Phillips, A. J. L., Alves, A., Abdollahzadesh, J., Slippers, B., Wingfield, M. J., Groenewald, J. Z., and Crous, P. W. 2013. The Botryosphaeriaceae: Genera and species known from culture. Stud. Mycol. 76:51-167.

Phillips, A. J. L., Crous, P. W., and Alves, A. 2007. Diplodia seriata, the anamorph of "Botryosphaeria" obtusa. Fungal Divers. 25:141-155.

Phillips, A. J. L., Fonseca, F., Povoa, V., Castilho, R., and Nolasco, G. 2002. A reassessment of the anamorphic fungus Fusicoccum luteum and description of its teleomorph Botryosphaeria lutea sp. nov. Sydowia 54:59-77.

Pintos Varela, C., Redondo Fernández, V., Aguín Casal, O., and Mansilla, J. P. 2011a. First report of cankers and dieback caused by Neofusicoccum mediterraneum and Diplodia corticola on grapevine in Spain. Plant Dis. 95: 1315.

Pintos Varela, C., Redondo Fernández, V., Mansilla, J. P., and Aguín Casal, O. 2011b. First report of dieback on hybrid Rhododendrons caused by Neofusicoccum luteum and N. parvum in Spain. Plant Dis. 95:221.

Punithalingam, E., and Waller, J. M. 1973. Botryosphaeria obtusa. CMI Descriptions of Pathogenic Fungi and Bacteria, No. 394. Commonwealth Mycological Institute, Kew, Surrey, UK

Pusey, P. L., Kitajima, H., and Wu, Y. 1995. Fungal gummosis. Pages 33-34 in: Compendium of Stone Fruit Diseases. J. M. Ogawa, E. I. Zehr, G. W. Bird, D. F. Ritchie, K. Uriu, and J. K. Uyemoto, eds. American Phytopathological Society, St. Paul, MN.

Rayner, R. W. 1970. A Mycological Color Chart. Commonwealth Mycological Institute and British Mycological Society, Kew, Surrey, UK

Roca, L. F., Raya, M. C., and Trapero, A. 2013. First report of Botryosphaeria dothidea causing fruit rot of plum in Spain. Plant Dis. 97:556.

Sergeeva, B., Alves, A., and Phillips, A. J. L. 2009. Neofusicoccum luteum associated with leaf necrosis and fruit rot of olives in New South Wales, Australia. Phytopathol. Mediterr. 48:294-298.

Sessa, L., Abreo, E., Betucci, L., and Lupo, S. Botryosphaeriaceae species associated with wood diseases of stone and pome fruits trees: Symptoms and virulence across different hosts in Uruguay. Eur. J. Plant Pathol. In press. doi:0.1007/s10658-016-0936-4
Slippers, B., Crous, P. W., Denman, S., Coutinho, T. A., Wingfield, B. D., and Wingfield, M. J. 2004. Combined multiple gene genealogies and phenotypic characters differentiate several species previously identified as Botryosphaeria dothidea. Mycologia 96:83-101.

Slippers, B., Smit, W. A., Crous, P. W., Coutinho, T. A., Wingfield, B. D., and Wingfield, M. J. 2007. Taxonomy, phylogeny and identification of Botryosphaeriaceae associated with pome and stone fruit trees in South African and other regions of the world. Plant Pathol. 56:128-139.

Thomidis, T., Michailides, T. J., and Exadaktylou, E. 2011. Neofusicoccum parvum associated with fruit rot and shoot blight of peaches in Greece. Eur. J. Plant Pathol. 131:661-668.

Trouillas, F. P., Úrbez-Torres, J. R., Peduto, F., and Gubler, W. D. 2010. First report of twig and branch dieback of English walnut (Juglans regia) caused by Neofusicoccum mediterraneum in California. Plant Dis. 94:1267.

Úrbez-Torres, J. R. 2011. The status of Botryosphaeriaceae species infecting grapevines. Phytopathol. Mediterr. 50:S5-S45.

Úrbez-Torres, J. R., and Gubler, W. D. 2009. Pathogenicity of Botryosphaeriaceae species isolated from grapevine cankers in California. Plant Dis. 93:584-592.

Úrbez-Torres, J. R., Peduto, F., and Gubler, W. D. 2010. First report of grapevine cankers caused by Lasiodiplodia crassispora and Neofusicoccum mediterraneum in California. Plant Dis. 94:785.

Urbez-Torres, J. R., Peduto, F., Vossen, P. M., Krueger, W. H., and Gubler, W. D. 2013. Olive twig and branch dieback: Etiology, incidence, and distribution in California. Plant Dis. 97:231-244.

van Niekerk, J. M., Crous, P. W., Groenewald, J. Z. E., Fourie, P. H., and Halleen, F. 2004. DNA phylogeny, morphology and pathogenicity of Botryosphaeria species on grapevines. Mycologia 96:781-798.

White, T. J., Bruns, T., Lee, S., and Taylor, J. 1990. Amplification and direct sequencing of fungal ribosomal RNA genes for phylogenetics. Pages 315-322 in: PCR Protocols: A Guide to Methods and Applications. M. A. Innis, D. H. Gelfand, J. J. Sninsky, and T. J. White, eds. Academic Press, San Diego, CA.

Wright, E. R., Mandolesi, A., Rivera, M. C., and Pérez, B. A. 2011. Neofusicoccum parvum, blueberry pathogen in Argentina. Acta Hortic. 926:619-623.

Zea-Bonilla, T., González-Sánchez, M. A., Martín-Sánchez, P. M., and PérezJiménez, M. 2007. Avocado dieback caused by Neofusicoccum parvum in the Andalucia region, Spain. Plant Dis. 91:1052. 